\title{
CCR5 Gene
}

National Cancer Institute

\section{Source}

National Cancer Institute. CCR5 Gene. NCI Thesaurus. Code C24270.

This gene is involved in G protein-coupled signal transduction and chemotaxis. 